Ann. Biol. anim. Bioch. Biophys., 1977, 17 (6), 1021-1033.

\title{
Lipoprotein lipase activity and composition of omental adipose tissue as related to lipid metabolism of the goat in late pregnancy and early lactation
}

\author{
par Y. CHILLIARD, D. SAUVANT, J. HERVIEU, Michelle DORLEANS, P. MORAND- \\ FEHR
}

Laboratoire de Recherches de la Chaire de Zootechnie, I. N. R. A.

Institut National Agronomique Paris-Grignon,

16, rue Claude Bernard 75231 Paris Cedex 05, France.

\begin{abstract}
Summary. Omental adipose tissue lipoprotein lipase (LPL) activity, nucleic acid content and triglyceride fatty acid composition were estimated on 5 goats in late pregnancy and early lactation. These data were compared with animal production parameters, plasma metabolife contents and milk triglyceride fatty acid composition.

Adipose tissue LPL activity and oleic acid content decreased whereas nucleic and stearic acid contents increased from pregnancy to lactation. Inter-goat variations were large for most parameters and emphasized a close relationship between decrease of LPL activity and decrease of omentum weight, measured on a DNA basis during that period. These decreases also correlated with parameter variations expressing the mobilization of goat body stores after parturition. Adipose tissue LPL activity of individual goats was very small in early lactation.
\end{abstract}

\section{Introduction.}

There are considerable changes in the fat metabolism of milk-yielding animals, particularly ruminants, during the reproductive cycle. The increase of plasma nonesterified fatty acid (NEFA) content in cows (Radloff et al., 1966 ; Decaen and Journet, 1967) and goats (Guessous et al., 1974) in early lactation results from a mobilization of adipose tissue. This is confirmed by a decrease of abdominal adipose tissue weight (Tulloh, 1966) and an increase of adipocyle lipolysis (Sidhu and Emery, 1972 ; Yang and Baldwin, 1973). NEFA are thus widely used for the synthesis of milk lipids (Hartmann and Lascelles, 1964). Simultaneously, the anabolic pathways of adipose tissue such as de novo synthesis of fatty acids, plasma triglyceride fatty acid uptake and triglyceride synthesis appear lower in the cow in early lactation (Benson, 1969 ; Baldwin and Smith, 1971 ; Shirley et al., 1973a).

Owing to recent data on the subject, this study has been orientated in two directions: - determination of differences in goat adipose tissue metabolism before and after parturition. Variations in adipose tissue nucleic acid and fatty acid contents have been 
defined as well as lipoprotein lipase (LPL) activity, which is one of the two pathways for supplying adipocytes with fatty acids. These determinations are completed by data on goat feeding, blood metabolites, milk yield and fatty acid composition.

- analysis of changes and interrelations of different parameters as related to the physiological state of the goats and to individual differences; the latter are of practical importance.

\section{Material and methods.}

Five 3-7-year old Alpine goats received lucerne hay ad libitum and a blend concentrate of grains, oilmeals, minerals and vitamins. During the last two months before parturition, the goats received $500 \mathrm{~g}$ of concentrates per day, then were given $400 \mathrm{~g}$ of concentrates per day and $275 \mathrm{~g}$ per $\mathrm{kg}$ of milk above a $2 \mathrm{~kg}$ production during lactation.

Daily amounts of ingested feed were determined individually. Weekly goat live weight, daily milk yield and weekly milk fat percentages were recorded. Feeds were analyzed by official methods.

Energy balance was estimated from ingested metabolizable energy using three equations :

Maintenance requirements : 90 milk kcal/ $\mathrm{W}^{0.75}$.

Milk energy $(\mathrm{kcal} / \mathrm{kg}): 312.92+11.17 \times$ fat percentage (Sauvant, CharletLery and Fehr, unpublished).

Coefficient of transformation from metabolizable energy to net energy $(\mathrm{kl})$ : $\mathrm{kl}=60+0.24(\mathrm{Q}-57)$ (Van Es, 1975).

Weight changes were not taken into account in this balance because of its poor significance during short periods.

At weeks 7 and 4 before parturition and at weeks 1, 3, 5 and 7 after parturition, $40 \mathrm{ml}$ of jugular vein blood were taken in the morning, a few minutes before biopsy or just after hay was distributed to the animals. Plasma lipids were measured according to the Chabrol and Charonnat (1937) reaction using an autoanalyzer ; glycemy was estimated by the method of Brown and Boston (1961) adapted by Bas (1976) to low concentrations of blood glucose in ruminants. Non-esterified fatty acids (NEFA) were determined by the semi-automatic method of Antonis (1965), $\beta$-hydroxybutyrate by the enzymatic method of Williamson and Mellanby (1974) modified by Bas and Lafond (unpublished), and plasma triglycerides according to the semi-enzymatic method of Eggstein and Kuhlmann (1974).

Milk samples proportional to two consecutive milkings were taken at weeks $1,3,5$ and 7 of lactation. The determination of milk triglyceride fatty acid composition was carried out as described by Bas (1976).

Adipose tissue was sampled by two biopsies on each goat, one at about 7 weeks before and one at 3 weeks after parturition. Biopsy samples were taken in the morning when animals had received no feed for about 12 hours. Goats were injected in the jugular vein with the tranquillizer Xylazine (« Rompun » Bayer A. G., Leverkusen, RFA). After subcutaneous infiltration of Procaine, a laparotomy was done to remove 20-50 $\mathrm{g}$ of adipose tissue from the great omentum (Omentum majus). 
Lipoprotein lipase activity of adipose tissue was determined by three extraction methods as described by Chilliard ef al. (1977) : in vitro incubation of minced tissue in a medium containing heparin and goat serum ; homogenization in an heparinized ammoniacal buffer ; homogenization of acetone-ether defatted powders in the heparinized ammoniacal buffer. As the data from these methods are comparable and highly correlated (Chilliard ef al., 1977), the average value of the three results is considered in this work.

Adipose tissue deoxyribonucleic acid (DNA) and ribonucleic acid (RNA) were determined as described by Durand et al. (1969), after tissue defatting with a method adapted to the high melting point of goat fat. The weight of fresh tissue corresponding to one $\mu$ mole of DNA bases (weight/DNA) was used as an indicator of the quantity of material associated with one adipose tissue nucleus (Durand ef al., 1965); this material includes fat cells and stromal cells and corresponds to mean tissue cellularity.

After extraction by chloroform-methanol (2V/1V) mixture, an aliquot of triglyceride fatty acids from $20 \mathrm{~g}$ of adipose tissue was transesterified by sodium methylate ( $\mathrm{Na} 1 \mathrm{p} .1000,3 \mathrm{ml}$ for $500 \mathrm{mg}$ fat). Methyl esters were analysed by gas-liquid chromatography.

The results were analyzed in several steps. After the description of parameter variations in time, variance analysis was applied to estimate the statistical significance of the differences observed in the adipose tissue during pregnancy and lactation. Intraand inter-goat correlation coefficients permitted us to begin to study the relations between parameters and individual variations. In the last phase, the principal components anclysis (Lebart and Fenelon, 1971) was used to cluster the observed relations and evaluate interindividual variations with more accuracy.

\section{Results.}

Feed intake returned to its previous level 2-5 days after biopsy and milk yield in less than 2 óays. Nevertheless, one goat aborted seven days after the first biopsy.

In comparison with the values observed during gestation, dry matter intake $\left(\mathrm{g} / \mathrm{d} / \mathrm{kg} \mathrm{W}^{0.75}\right)$, energy balance and plasma triglyceride concentration were clearly lower during the first week of lactation. On the other hand, plasma NEFA and $\beta$-hydroxybutyrate contents were considerably higher (fig. 1, 2). Just after parturition, milk fat percentage was very high cs was stearic (C18:0) and oleic (C18:1) acid contents in milk fat (fig. 3). Dry matter intake, energy balance, milk yield increased, fat percentage and $\mathrm{C} 18 \mathrm{fctty}$ acid percentage decreased later when the proportion of shorter chain acids rose. Blood plasma total lipids increased, NEFA and $\beta$-hydroxybutyrate contents decreased progressively, and glucose and triglyceride contents varied slightly.

The inter-animal variations in plasma triglyceride content were higher during gestation. On the contrary, those of plasma NEFA and $\beta$-hydroxybutyrate were higher during lactction. During gestation, the coefficients of inter-animal correlation between dry matter intake and hay proportion in the diet or plasma $\beta$-hydroxybutyrate content were positive and significant $(P<5$ p. 100). The coefficients of intra-animal correlation between proportions of hay, dry matter intake and energy balance were 
positive and highly significant $(P<1$ p. 100). Energy balance was positively and significantly correlated $(P<10$ p. 100) with plasma triglyceride content and, in a lesser degree, with plasma $\beta$-hydroxybutyrate content.

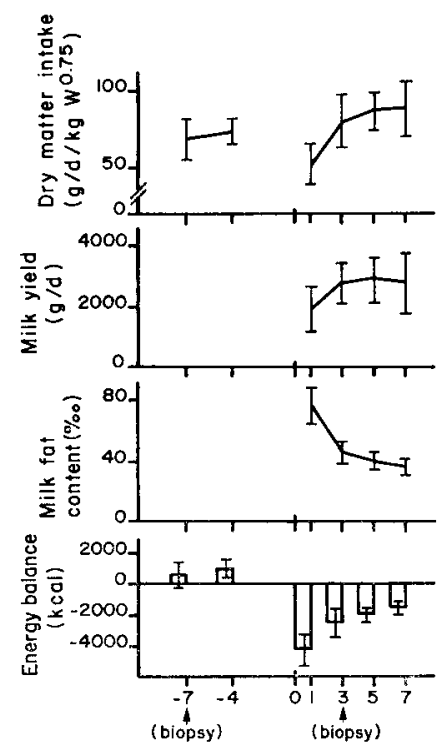

FIG. 1. - Evolution of some parameters of animal production.

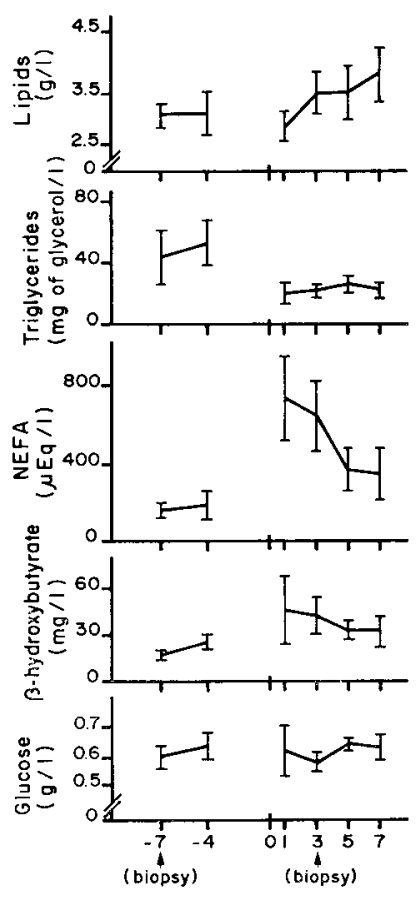

FIG. 2. - Evolution of plasma metabolite concentrations.

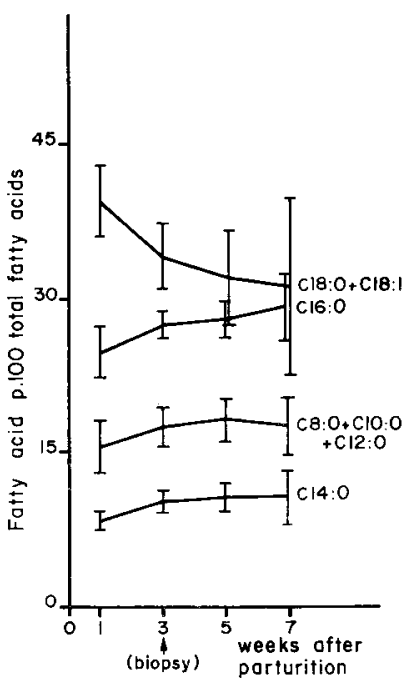

FIG. 3. - Evolution of milk triglyceride fatty acid composition.

The mean \pm (standard deviation) of the results obtained on 4 pregnant goats and 5 lactating goats is presented.

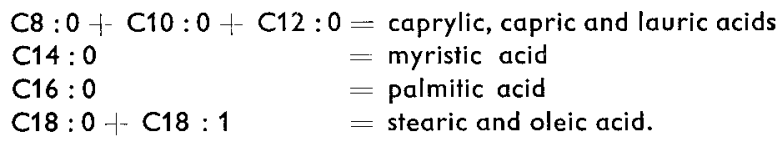

In lactation, the coefficients of inter-animal correlation between dry matter intake and plasma $\beta$-hydroxybutyrate and triglyceride contents $(P<10$ p. 100) and milk yield ( $P<5$ p. 100) were positive. Energy balance and plasma glucose content were positively correlated $(P<1$ p. 100). Palmitic acid percentage in milk fat was positively correlated with dry matter intake $(P<10$ p. 100), triglyceridemia $(P<$ 1 p. 100) and myristic acid percentage $(P<5$ p. 100). On the other hand, stearic and oleic acid percentages were negatively correlated with dry matter intake and triglyceridemia $(P<5$ p. 100) and shorter chain acid percentages $(P<5$ or 1 p. 100). The intra-animal correlation coefficients confirmed changes according to time (figs. 1 , $2,3)$. 
Adipose tissue nucleic acid contents were usually higher in early lactation than in late gestation (table 1). The RNA/DNA ratio varied little in individual goats. The average size of cells estimated by the « weight/DNA » ratio, tended to be lower in early lactation. Adipose tissue LPL activity per gram of tissue or as related to DNA was three of five times lower in early lactation than in late gestation ; inter-animal variations were less in lactation than in gestation, while those of nucleic acid content were greater. The logarithmic transformation of LPL activities recommanded by Persson (1973) for man did not change the already-observed trends; the differences between gestation and lactation were more significant $(P<5$ p. 100).

\section{TABLE 1}

LPL activity and nucleic acid content of adipose tissue in late pregnancy and early lactation

\begin{tabular}{|c|c|c|c|c|}
\hline & \multirow[b]{2}{*}{ Pregnancy } & \multirow[b]{2}{*}{ Lactation } & \multicolumn{2}{|c|}{ Significance of the effects } \\
\hline & & & $\begin{array}{c}\text { Physiological } \\
\text { state }\end{array}$ & $\begin{array}{c}\text { Individual } \\
\text { (goat) }\end{array}$ \\
\hline $\begin{array}{l}\text { RNA content } \\
\qquad(\mu \text { mole of bases } / g) \ldots .\end{array}$ & $0.13( \pm 0.04) *$ & $0.22( \pm 0.24)$ & N.S. & N.S. \\
\hline $\begin{array}{l}\text { DNA content } \\
\quad(\mu \text { mole of bases } / g) \ldots \ldots \ldots . .\end{array}$ & $0.22( \pm 0.03)$ & $0.39( \pm 0.14)$ & $P<0.25$ & N. S. \\
\hline $\begin{array}{l}\text { Tissue } \ll \text { weight } / \text { DNA } » \\
\quad(g / \mu \text { mole of bases }) \ldots \ldots . .\end{array}$ & $4.81( \pm 0.60)$ & $3.64( \pm 0.78)$ & $P<0.25$ & $P<0.25$ \\
\hline $\begin{array}{l}\text { LPL activity } \\
\quad(\mu \mathrm{Eq} \mathrm{FA} / \mathrm{h} / \mathrm{g}) \ldots .\end{array}$ & $6.70( \pm 2.37)$ & $2.27( \pm 0.80)$ & $P<0.10$ & $P<0.25$ \\
\hline $\begin{array}{l}\text { LPL/DNA } \\
(\mu \text { Eq FA } / \mathrm{h} / \mu \text { mole of bases }) \ldots .\end{array}$ & $30.9( \pm 10.7) *$ & $6.06( \pm 0.95)$ & $P<0.10$ & N.S \\
\hline
\end{tabular}

* Mean \pm standard error (5 goats)

In three goats $(28,35$ and 42 , fig. 4) adipose tissue « weight/DNA » and LPL activity/DNA decreased considerably from gestation to lactation ; it was the contrary in two other goats (43 and 58). Changes in these two parameters were closely and linearly correlated; the straight line $\Delta$ (fig. 4) classifies goats according to the degree of change. Several indications of fat depot mobilization in early lactation such as decrease of live weight during the first month of lactation, plasma NEFA and $\beta$-hydroxybutyrate contents, and changes in milk C18 fatty acid percentages confirmed this classification (fig. 5).

Adipose tissue triglyceride fatty acid composition varied from gestation to laciation. Oleic acid percentage decreased when stearic percentage increased (table 2). There was considerable inter-animal variation, particularly for stearic and linoleic acid percentages. 


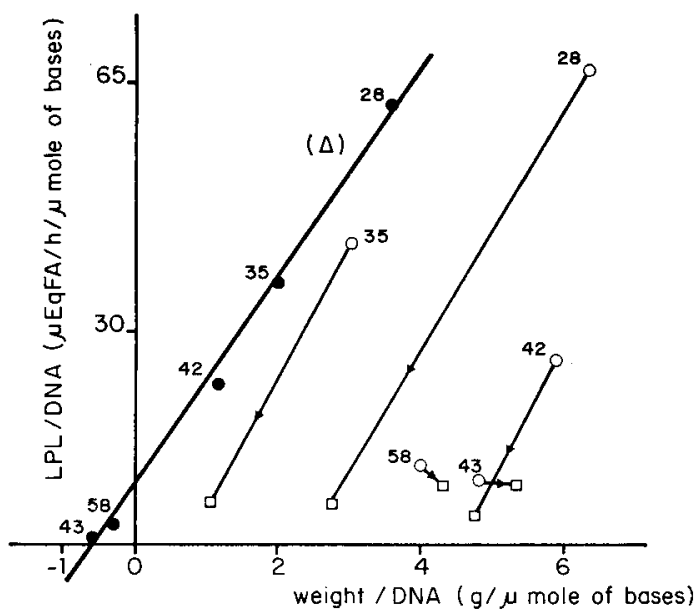

FIG. 4. - Simultaneous evolution of adipose tissue "weight/DNA " and LPL activity/DNA between late pregnancy and early lactation.

Each goat is codated by a number.

$\mathrm{O}=$ late pregnancy values

$\square=$ early lactation values

- = points resulting from the substraction of lactation values from gestation values on each axis

Equation of the straight line $(\Delta): Y=a X+b$ with :

$$
\begin{aligned}
& Y=\left(\frac{L P L}{D N A}\right) \text { pregnancy }-\left(\frac{L P L}{D N A}\right) \text { lactation } \\
& X=\left(\frac{\text { weight }}{D N A}\right) \text { pregnancy }-\left(\frac{\text { weight }}{\text { DNA }}\right) \text { lactation }
\end{aligned}
$$

$a, b=$ constants.

TABLE 2

Adipose tissue triglyceride fatty acid composition in late pregnancy and early lactation

\begin{tabular}{lcccc}
\hline \multicolumn{1}{c}{ Fatty acid } & Pregnancy & Lactation & $\begin{array}{c}\text { Significance of the effects } \\
\begin{array}{c}\text { Physiological } \\
\text { sfate }\end{array}\end{array}$ & $\begin{array}{c}\text { Individual } \\
\text { (goat) }\end{array}$ \\
\hline Myristic acid (p. 100) $\ldots \ldots \ldots$ & $3.7( \pm 0.2)^{*}$ & $3.6( \pm 0.1)$ & N. S. & $P<0.10$ \\
\hline Palmitic acid (p. 100) $\ldots \ldots \ldots$ & $32.1( \pm 0.8)$ & $32.7( \pm 0.8)$ & N. S. & $P<0.25$ \\
\hline Stearic acid (p. 100) $\ldots \ldots \ldots$ & $28.9( \pm 1.1$ & $31.2( \pm 0.9)$ & $P<0.05$ & $P<0.05$ \\
\hline Oleic acid (p. 100) $\ldots \ldots \ldots$ & $27.0( \pm 0.9)$ & $24.1( \pm 0.5)$ & $P<0.05$ & $P<0.25$ \\
\hline Linoleic acid (p. 100) $\ldots \ldots \ldots$ & $1.3( \pm 0.2)$ & $1.4( \pm 0.2)$ & N. S. & $P<0.05$ \\
\hline
\end{tabular}

* Mean \pm standard error (5 goats). 


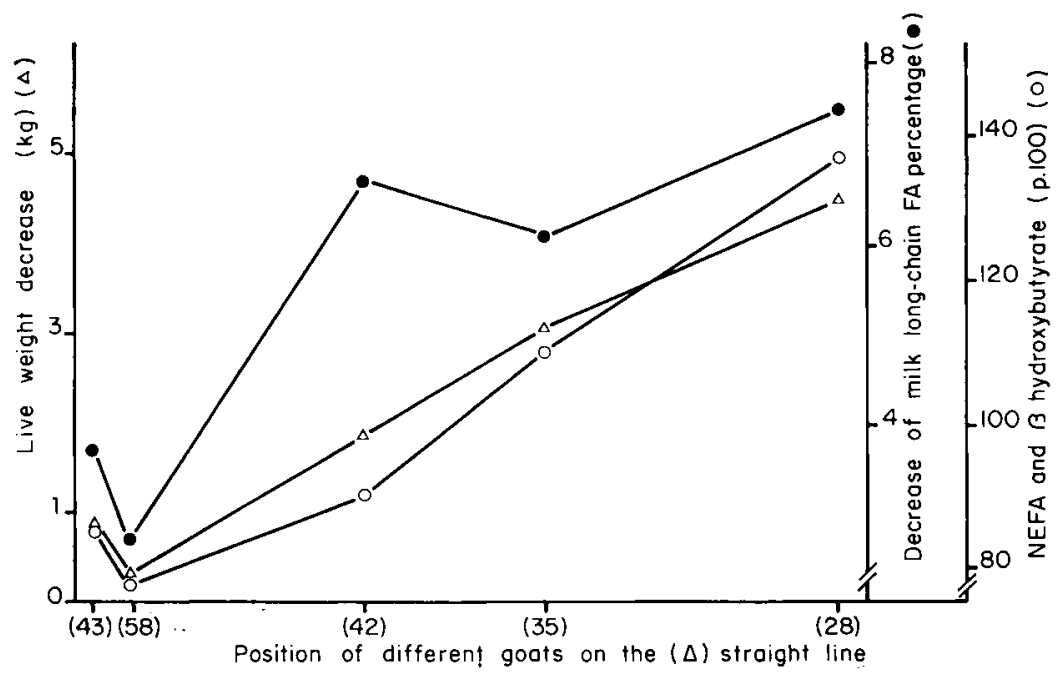

FIG. 5. - Comparison of inter-goaf storage mobilization criteria.

The following parameters are presented on the $y$-axis :

- live weight decrease of the goats between weeks 1 and 3 of lactation ;

- decrease of stearic and oleic acid percentages in milk fatty acids between weeks 1 and 3 of lactation ;

- index for plasma NEFA and $\beta$-hydroxybutyrate concentrations at week 3 of lactation. The combined mean value of these two parameters is taken as 100 .

Goats'numbers $(X)$ are shown on the $X$-axis according to their position on the $(\Delta)$ straight line of fig. 4.

To emphasize possible relationships between feed intake, blood plasma and adipose tissue composition and LPL activity, 13 of the parameters considered on the five goats were compared in gestation and in lactation. Principal components analysis was applied to these 130 data to cluster the main variation sources.

The first component explains 42 p. 100 of the variations of the whole data. A variance analysis was applied to the ordinate values of the ten « animal-physiological state » points on this component (Jeffers, 1962). The first component mainly traducts variations due to the physiological state of the animals $(P<0.01)$ but not to individual differences. More than 50 p. 100 of the variance of 7 parameters is explained by this first component, i.e. p. 100 of oleic acid in adipose tissue, p. 100 of hay in the diet, plasma triglyceride content, energy balance, LPL/DNA activity (higher in pregnancy), and plasma $\beta$-hydroxybutyrate and NEFA contents (higher in lactation). These parameters are principally affected by change in the physiological state.

The second principal component explains 23 p. 100 of the data variations that do not depend on the variations on the first component. They only traduct individual differences (significant effect, $P<0.01$ ). Figure 6 shows the significant inter-individual effect considered on the second component. This effect is due to a set of mutual opposite parameters between goats 42 and 35 . Indeed, correlations of the considered para- 
meters with this component (fig. 6) show that, as compared with goats 43, 58 and 28 and contrary to goat 42 , animal 35 has a high level of dry matter intake, adipose tissue characterized by small-sized cells (fig. 4) and a high $18: 2 / 16: 0$ ratio.

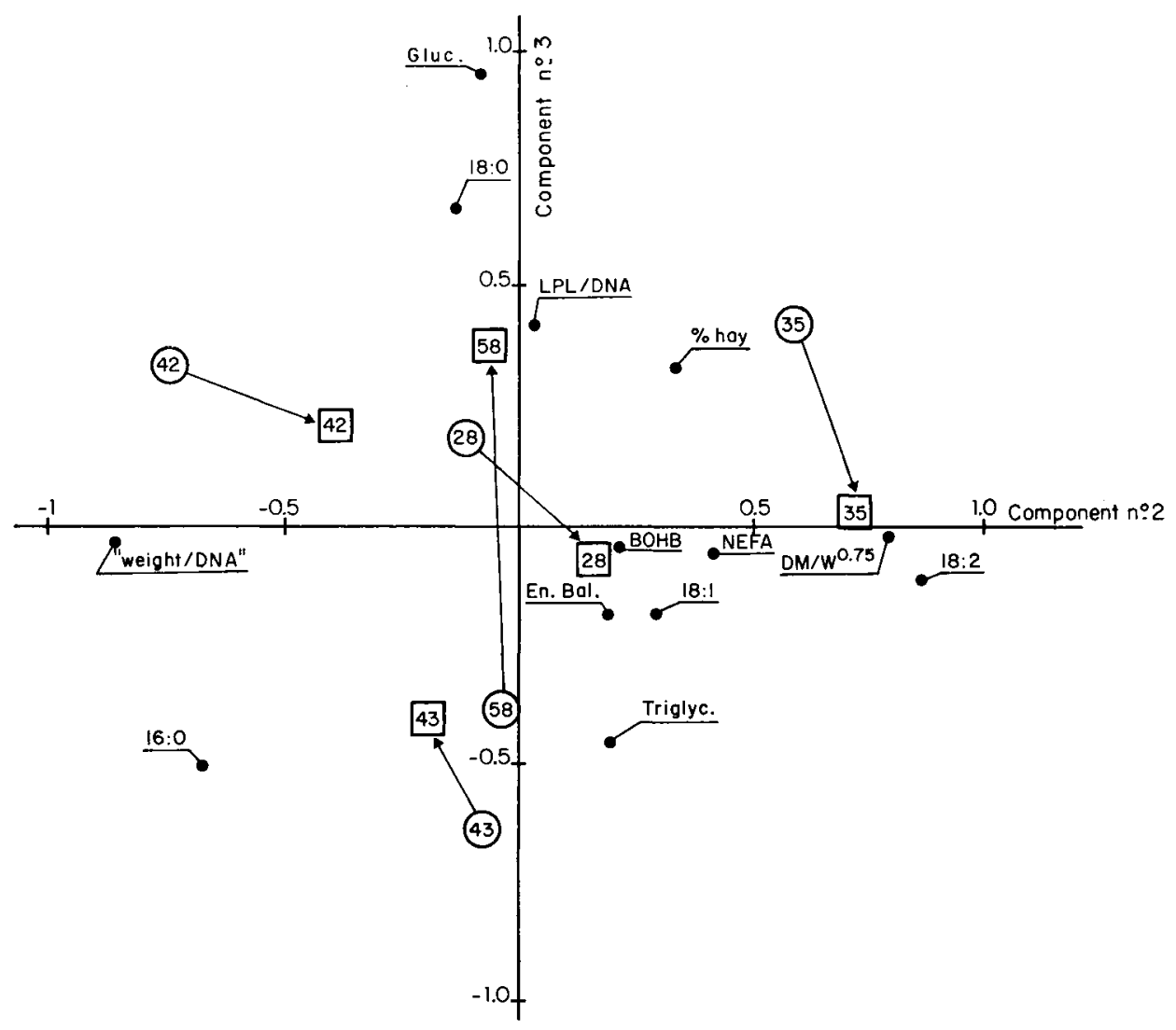

FIG. 6. - Projection of " animal-physiological state " points and parameters on the 2-3 principal components plan.

animal-gestation point

$\rightarrow \square$ animal-lactation point.

The 13 considered parameters are : hay percentage in the diet; dry matter intake (DM/ $W^{0,75}$ ) ; energy balance ; plasma glucose, triglyceride, $\beta$-hydroxybutyrate and NEFA concentrations ; adipose tissue "weight/DNA" and LPL activity ; palmitic, stearic, oleic and linoleic acid proportions in adipose tissue triglycerides.

Projections of the parameters on the axis indicate the correlation coefficients between the parameters and the principal components.

The third principal component explains 17 p. 100 of the data variations. These variations correspond to the particularity of goat 43 and the opposite evolutions from pregnancy to lactation of goats 58 and 43 on one hand and goats $42,28,35$ on the 
other. These variations correspond to LPL/DNA activity (fig. 4) and to the plasma glucose and adipose stearic acid contents. The three parameters vary on this component as opposed to plasma triglyceride and adipose palmitic acid contents.

\section{Discussion.}

Variations in feed intake, milk yield and composition and plasma metabolites in late gestation and the first weeks of lactation are comparable with other results in cows and goats (Storry and Rook, 1964 ; Hartmann and Lascelles, 1964 ; Remond ef al., 1973 ; Guessous et al., 1974) ; restricted intake ability in early lactation cannot meet milk energetic requirement. Consequently, after parturition goats have the metabolic profiles of lactating and energy-deficient animals, i.e. high plasma NEFA and $\beta$-hydroxybutyrate concentrations, increased milk fat percentage, high percentage of C18 fatty acids in milk fat. After several weeks of lactation, goat intake ability improves and nutritional parameters tend to return to the values of a balanced energy state.

In goat adipose tissue, the drop in LPL activity from late gestation to early lactation is related to a decrease in individual variability. These evolutions suggest that LPL activity decreases after parturition to a basal level corresponding to lowest adipose tissue competition with the mammary gland for uptake of plasma triglyceride fatty acids. The same tendency appears from data obtained in pregnant and lactating cow and rat (Otway and Robinson, 1968 ; Hamosh et al., 1970 ; Shirley et al., 1973a).

The low LPL activity in early lactation would result from hormonal changes due to lactational state or/and energy balance (Shirley ef al., 1973b). Indeed prolactin (Zinder ef al., 1974) and estrogens (Hamosh and Hamosh, 1975), cyclic AMP and several lipolytic hormones (Robinson and Wing, 1970) decrease adipose tissue LPL activity in the rat. On the other hand, insulin in cow (Rao et al., 1973) and some antilipolytic drugs (Robinson and Wing, 1970) increase adipose LPL activity.

This study reports simultaneous data on the variation of anabolic enzymatic activity and that of average-sized cells resulting from overall adipose tissue metabolism. The close inter-animal relation between the variations of these two parameters could indicate well-coordinated regulation of the anabolic and catabolic pathways. In fact, variations in the nutritional and hormonal states might modify lipomobilization and lipid storage activities (LPL, de novo fatty acid synthesis, glyceride synthesis) in an opposite way (Angel and Roncari, 1967 ; Benson, 1969 ; Baldwin and Smith, 1971 ; Shirley et al., 1973a, b ; Lynen, 1973 ; Denton, 1975). This relationship also suggests that LPL activity may have a significant effect on dairy goat adipose tissue metabolism, though this tissue is usually considered as the main region of de novo fatty acid synthesis in ruminants (Ingle et al., 1972). Otherwise, subjective observations made during biopsy on the fat density of adipose tissue are confirmed and quantified by the weight/ DNA ratios.

The passage from pregnancy to lactation is accompanied by stearic acid increase and oleic acid decrease in adipose tissue. Studies on plasma or hepatic lipid fatty acid composition lead to the hypothesis of a preferential release of oleic acid from the adipose tissue when the ruminant presents a negative energetic balance (Mulder, 
1971 ; Smith and Walsh, 1975 ; Thompson and Darling, 1975 ; Sauvant and Chilliard, unpublished). Other hypotheses, which do nct contradict the one mentioned above, could be envisaged ; thus Garton and Wahle (1975) observed a decrease of adipose tissue desaturase activity in the rat with a $n \in g$ c tive energetic balance.

The study of inter-goat correlation coefficients confirmed variations in milk lipid fatty acid composition from one animal to another, independent from the lactation stage ; it particularly supported substitution between 18-carbon fatty acids and shorter chain fatty acids. Moreover, the animals providing a milk rich in long-chain fatty acids had low levels of dry matter intake and low amounts of plasma triglycerides. Similar relations are described by Sauvant (1973) in another goat experiment.

Principal components analysis was used to cluster the variations of the various parameters according to physiological state and individual influences. On the second principal component, the animals consuming more dry matter had adipose tissue containing a higher level of triglyceride linoleic acid. This relation could be caused by the exclusively exogenous origin of the acid. The reverse relationship between feed intake level and adipose cell size is difficult to explain in the present state of our knowledge.

The third principal component emphasizes relationships hidden by the physiological and individual effects on the first two components. The opposition between the evolutions of animals 43 and 58 on one hand, and 42,35 and 28 on the other in figures 4 and 5 , is now confirmed when the main parameters measured are considered together; this opposition does not appear in relation with the 4 p. 100 corrected milk yield in this experiment. On the other hand, a high level of adipose tissue LPL activity tends to be accompanied by high plasma glucose content and low plasma triglyceride concentration ; this could express a direct or indirect effect of blood glucose on adipose LPL activity and an influence of this activity on the plasma triglyceride content. The simultaneous decrease of adipose LPL activity and plasma triglyceride content observed from one biopsy to the other were taken into account by the first principal component, and could be closely related to the high level of mammary LPL activity observed in early lactation in rat, cow and goat (Hamosh ef al., 1970 ; Shirley et al., 1973a,b ; Chilliard, unpublished).

\section{Conclusion.}

This experiment reports a synthetic view of the evolution of goat adipose tissue and lipid metabolism before and after parturition. Omental LPL activity at 7 weeks before parturition is five times higher than the corresponding activity at the beginning of lactation. During this period, the inter-goat variations in LPL activity and the average size of adipose tissue cells, are similar. These variations are positively correlated with the blood metabolites which reflect the mobilization of adipose stores in early lactation, i.e. NEFA and $\beta$-hydroxybutyrate. The evolution of the proportion of 18-carbon fatty acids in milk triglycerides also confirms this mobilization. The study of oleic acid variation in adipose tissue could be used to characterize lipid store mobilization in the dairy goat.

The present experiment emphasizes important individual variations in most parameters studied. These variations are seldom taken into account (Sauvant and 
Fehr, unpublished). This indicates the necessity of such studies for characterizing possible types of lipid metabolism in goats during changes in the physiological state and the feeding conditions.

Reçu en ooat 1976.

Accepté en juin 1977.

Acknowledgements. - We wish to thank Mr. G. Durand who allowed us to carry out the measurement of nucleic acids at the INRA station at Jouy-en-Josas (France). We also wish to thank Miss N. Bourgeaux, Mr. P. Bas, Mrs. J. Lafond and Mr. A. Cucci for their able assistance during this work.

Résumé. L'activité lipoprotéine-lipasique ( $L P L$ ), la teneur en acides nucléiques ef la composition en acides gras du tissu adipeux épiploïque de 5 chèvres en fin de gestation et en début de lactation sont déterminées et confrontées aux évolutions des caractéristiques zootechniques, des concentrations en métabolites plasmatiques et de la composition en acides gras de la matière grasse du lait.

Le passage de la gestation à la lactation s'accompagne d'une diminution de l'activité LPL et d'une augmentation de la teneur en acides nucléiques du tissu adipeux, ainsi que d'un appauvrissement du tissu en acide oléique, et d'un enrichissement en acide stéarique. Les variations entre chèvres sont importantes pour la plupart des caractéristiques étudiées. Une relation interchèvre très étroite existe entre les diminutions, au cours de cette période, de l'activité LPL et de la masse de l'épiploon, exprimées en fonction de la teneur en DNA. Ces diminutions sont aussi liées aux variations de paramètres reflétant l'état de mobilisation des réserves corporelles de chaque chèvre après la parturition. Toutefois, l'activité LPL du tissu adipeux est très faible chez toutes les chèvres en début de lactation.

\section{References}

ANGEL A., RONCARI D. A. K., 1967. The control of fatty acid esterification in a subcellular preparation of rat adipose tissue. Biochim. biophys. Acta, 137, 464-474.

ANTONIS A., 1965. Semiautomated method for the colorimetric determination of plasma free fatty acids. J. Lipid Res., 6, 307-312.

BALDWIN R. L., SMITH N. E., 1971. Intermediary aspects and tissue interactions of ruminant fat metabolism. J. Dairy Sci., 54, 583-595.

BAS P., 1976. Influence du propionate de sodium et de la nicotinamide sur le métabolisme lipidique de la chèvre en lactation. Thèse C. N. A. M., Paris, France.

BENSON J. D., 1969. Lipid metabolism in bovine liver and adipose tissue. Ph. D. thesis, Michigan State, East Lansing, U. S. A.

BROWN M. E., BOSTON M. S., 1961. Ultra-micro sugar determinations using 2,9 dimethyl, 1, 10 phenanthroline hydrochlorhyde (Neocuproine). Diabetes, 10, 60.

CHABROL E., CHARONNAT R., 1937. Une nouvelle réaction pour l'étude des lipides. L'oléidémie. Presse méd., 45, 1713.

CHILLIARD Y., DORLEANS M., FEHR P. M., 1977. Mise en évidence d'une activité lipoprotéinelipasique dans le tissu adipeux de chèvre : comparaison de trois méthodes d'extraction. Ann. Biol. anim. Bioch. Biophys., 17, 107-122.

DECAEN C., JOURNET M., 1967. Evolution au début de la lactation de la sécrétion des principaux acides gras du lait ef de la concentration en acides gras libres du sang chez la vache. Ann. Biol. anim. Bioch. Biophys., 7, 131-143.

DENTON R. M., 1975. Hormonal regulation of fatty acid synthesis in adipose tissue through changes in the activities of pyruvate deshydrogenase and acetyl-CoA carboxylase. Proc. Nutr. Soc., 34, 217-224. 
DURAND G., FAUCONNEAU G., PENOT E., 1965. Etude biochimique de la croissance de l'intestin grêle, du foie et de la carcasse du rat ; rôles respectifs de la multiplication et du grandissement cellulaires. Ann. Biol. anim. Bioch. Biophys., 5, 163-187.

DURAND G., FAUCONNEAU G., PENOT E., 1969. Répartition des cellules entre les tissus du rat adulte, préalablement soumis à une sous-nutrition énergétique temporaire à deux stades de la croissance. Ann. Biol. anim. Bioch. Biophys., 9, 55-73.

EGGSTEIN M., KUHLMANN E., 1974. Triglycerides and glycerol ; determination after alkaline hydrolysis, 1825-1831. In : BERGMEYER H. U., Methods of enzymatic analysis, Verlag Chemie, Weinheim, R. F. A.

GARTON G. A., WAHLE K. W., 1975. Effects of diet on fatty acid metabolism. Proc. Nutr. Soc., 34, 257-264.

GUESSOUS F., FEHR P. M., DELAGE J., 1974. Influence de l'acétate et du propionate de Na ajoutés au régime avant et après la mise bas sur le métabolisme, la production ef la composition lipidique du lait de chèvre. Ann. Biol. anim., Bioch. Biophys., 14, 261-269.

HAMOSH M., CLARY T. R., CHERNICK S. S., SCOW R. O., 1970. Lipoprotein lipase activity of adipose and mammary tissue and plasma triglyceride in pregnant and lactating rats. Biochim. biophys. Acta, 210, 473-482.

HAMOSH M., HAMOSH P., 1975. The effect of estrogen on the lipoprotein lipase activity of rat adipose tissue. J. clin. Invest., 55, 1132-1135.

HARTMANN P. E., LASCELLES A. K., 1964. The uptake of plasma lipid and some non lipid constituents by the mammary gland of the cow. Austr. J. biol. Sci., 17, 935-944.

INGLE D. L., BAUMAN D. E., GARRIGUS U. S., 1972. Lipogenesis in the ruminant : in vitro study of tissue sites, carbon source and reducing equivalent generation for fatty acid synthesis. J. Nutr., 102, 609-616.

JEFFERS J. N. R., 1962. - Principal component analysis of designed experiment. The statistician, 12, 230-242.

LEBART L., FENELON J. P., 1971. Statistique ef informatique appliquées. Dunod, Paris, France.

LYNEN F., 1973. Fatty acid synthesis and its regulation on the enzyme level. In : MENKE K. H., LANTZSCH H. J., REICHL J. R., 1974, Proc. 6th Symp. on Energy metabolism of farm animals (E. A. A. P.), 9-34, Universität Hohenheim, RFA.

MULDER 1., 1971. Changes in fatty acid pattern in bovine plasma. Biochem. J., 122, 12-13 pp.

OTWAY S., ROBINSON D. S., 1968. The significance of changes in tissue clearing-factor lipase activity in relation to the lipaemid of pregnancy. Biochem. J., 106, 677-682.

PERSSON B., 1973. Lipoprotein lipase activity of human adipose tissue in different types of hyperlipidemia. Acta med. scand., 193, 447-456.

RADLOFF H. D., SCHULTZ L. H., HOEKSTRA W. G., 1966. Relationship of plasma free fatty acids to other blood components in ruminants under various physiological conditions. J. Dairy Sci., 49, 179-182.

RAO D. R., HAWKINS G. E., SMITH R. C., 1973. Effect of glucose and insulin on lipoprotein lipase activity in adipose tissue and milk. J. Dairy Sci., 56, 1415-1419.

REMOND B., TOULLEC R., JOURNET M., 1973. Evolution à la fín de la gestation et au début de la lactation des teneurs des différents constituants du sang, principalement des fractions lipidiques. Relations avec la sécrétion des matières grasses du lait. Ann. Biol. anim. Biochem. Biophys., 13, 455-469.

ROBINSON D. S., WING D. R., 1970. Regulation of adipose tissue clearing factor lipase activity. Horm. Mefab. Res., 2 (suppl. 2), 41-46.

SAUVANT D., 1973. Origine mammaire ef extra-mammaire des acides gras du lait de chèvre. Interactions entre les acides acétique et stéarique. Thèse de Doct.-Ing., Univ. P. et M. Curie, Paris, France.

SIDHU K. S., EMERY R. S., 1972. Regulation of blood fatty acids and glycerol in lactating cows. J. Dairy Sci., 55, 926-930.

SHIRLEY J. E., EMERY R. S., CONVEY E. M., OXENDER W. D., 1973a. Enzymic changes in bovine adipose and mammary fissue, serum and mammary tissue hormonal changes with initiation of lactation. J. Dairy Sci., 56, 569-574.

SHIRLEY J. E., MORROW D., EMERY R. S., 1973b. Mammary and adipose lipoprotein lipase and glyderide synthetase as regulator of blood fat uptake. J. Nutr., 103, XXII (Abstr.). 
SMITH R. W., WALSH A., 1975. The composition of the llver liplds of the ewe during pregnancy and lactation. Res. Vet. Sci., 19, 230-232.

STORRY J. E., ROOK J. A. F., 1964. Lipids in the blood plasma of cows of the Friesan and Channel Island Breeds. Nature, 201, 4922-4926.

THOMPSON G. E., DARLING K. F., 1975. The hepatlc uptake of individual free fatty acids in sheep during noradrenaline infusion. Res. Vet. Sci., 18, 325-327.

TULLOH N. M., 1966. Physical studies of the alimentary tract of grazing cattle. IV. Dimensions of the tract in lactating and non lactating cows. N. Z. J. agric. Res., 9, 999-1008.

VAN ES A. J. F., 1975. Feed evaluation for dairy cows. Livest. Prod. Sci., 2, 95-107.

WILLIAMSON D. H., MELLANBY J., 1974. D-(-)-3-Hydroxybutyrate, 1836-1839. In : BERGMEYER H. U., Methods of enzymatic analysis, Verlag Chemie, Weinheim, R. F. A.

YANG Y. T., BALDWIN R. L., 1973. Lipolysis in isolated cow adipose cells. J. Dairy Sci., 56, 366-374.

ZINDER O., HAMOSH M., FLECK T. R. C., SCOW R. O., 1974. Effect of prolactin on lipoprotein lipase in mammary gland and adipose fissue of rats. Amer. J. Phys., 226, 744-748. 